\title{
Parasitism of photosynthetic dinoflagellates in a shallow subestuary of Chesapeake Bay, USA
}

\author{
D. W. Coats*, E. J. Adam, C. L. Gallegos, S. Hedrick \\ Smithsonian Environmental Research Center, PO Box 28, Edgewater, Maryland 21037, USA
}

\begin{abstract}
Rhode River (USA) populations of the red-tide dinoflagellates Gymnodinium sanguineum Hirasaka, 1922, Gyrodinium uncatenum Hulburt, 1957, and Scrippsiella trochoidea (Stein) Loeblich III, 1976, were commonly infected by their parasitıc relative Amoebophrya ceratii Cachon, 1964, during the summer of 1992. Mean infection levels were relatively low, with data for vertically integrated samples averaging $1.0,1.9$, and $6.5 \%$ for $C$. sanguineum, G. uncatenum, and S. trochoidea, respectively. However, epidemic outbreaks of $A$. ceratii (20 to $80 \%$ hosts parasitized) occurred in G. uncatenum and $S$ trochoidea on several occasions, with peak levels of parasitism associated with decreases in host abundance. Estimates for parasite induced mortality indicate that $A$. ceratii is capable of removing a significant fraction of dinoflagellate biomass, with epidemics in the upper estuary cropping up to $54 \%$ of the dominant bloom-forming species, G. uncatenum, daily. However, epidemics were usually geographically restricted and of short duration, with daily losses for the 3 host species due to parasitism averaging 1 to $3 \%$ over the summer. Thus, $A$. ceratii appears capable of exerting a controlling influence on bloom-forming dinoflagellates of the Rhode River only when conditions are suitable for production of epidemic infections. Interestingly, epidemics failed to occur in multiple dinoflagellate taxa simultaneously, even when alternate host species were present at high densities. This observation, along with laboratory experiments demonstrating that parasites isolated from $G$. sanguineum were unable to infect $G$. uncatenum, $S$. trochoidea, and Ceratium furca, suggests that the dinoflagellate taxon $A$. ceratil may represent a cluster of relatively host-specific species.
\end{abstract}

KEY WORDS: Dinoflagellate $\cdot$ Parasitısm $\cdot$ Red tide

\section{INTRODUCTION}

Microparasites including viruses, bacteria, fungi, and protozoa have been recorded from marine and freshwater environments for many decades (Chatton 1920, Canter \& Lund 1948, Spencer 1955); however, their relative abundance and ecological significance in pelagic food webs have received little attention until recently. Lytic viruses are now thought to play a major role in the mortality of marine bacteria and phytoplankton, with the potential of causing population level changes in host organisms on time scales of hours to days (Bratbak et al. 1993, Nagasaki et al. 1994, Suttle 1994, Suttle \& Chan 1995). Similarly, fungal parasites of freshwater diatoms and dinoflagellates have

·E-mail: coats@serc.si.edu been implicated in mass mortalities of host organisms, suppression or retardation of phytoplankton blooms, and selective effects on species composition leading to successional changes in plankton communities (Canter \& Lund 1948, Reynolds 1973, Youngman et al. 1976, Van Donk \& Ringelberg 1983, Sommer et al. 1984, Heaney et al. 1988, Kudoh \& Takahashi 1990, Bruning et al. 1992). Fewer studies have considered protozoan parasites of planktonic organisms, but at least 1 group of protists, the parasitic dinoflagellates, appears sufficiently common and widespread to be of ecological significance (Drebes 1984, Cachon \& Cachon 1987). For example, parasitism by dinoflagellates has been estimated to account for about a third of total mortality in the pelagic copepod Paracalanus indicus (Kimmerer \& McKinnon 1990) and to crop ciliated protozoa at rates equivalent to grazing pressure from metazoan predators (Coats \& Heisler 1989, Coats et al. 1994). 
Dinoflagellates of the genus Amoebophrya are frequent parasites of marine protists including radiolaria, ciliates, and other dinoflagellates, with 1 species, $A$. rosei, also infecting chaetognaths and siphonophores Of the 7 species of Amoebophrya recognized by Cachon \& Cachon (1987), only A. ceratii is known to parasitize its free-living, photosynthetic relatives (Cachon 1964, Cachon \& Cachon 1987). This parasite appears to have little host specificity and is broadly distributed in the northern hemisphere, with infections recorded for over 20 species representing 18 genera of dinoflagellates from coastal waters of the Mediterranean Sea, Atlantic and Pacific Oceans, and Chesapeake Bay, USA (Cachon 1964, Taylor 1968, Elbrächter 1973, Nishitani et al. 1985, Fritz \& Nass 1992, Coats \& Buchstahler 1994). A. Coratii has a relatively short generation time $\left(<2 \mathrm{~d}\right.$ at $\left.23^{\circ} \mathrm{C}\right)$ and a simple life cycle that encompasses an intracellular growth phase followed by an extracellular reproductive phase that culminates in the production of infective dinospores (Coats \& Bockstahler 1994). During the intracellular phase, $A$. ceratii consumes the nucleus and cytoplasm of its host, thereby preventing reproduction and eventually killing the infected organism. Infection levels ranging from 2 to $80 \%$ have been reported for several host taxa, with epidemic outbreaks believed to exert a controlling influence on the development and dissipation of red tides (Cachon 1964, Nishitani et al. 1985). As a result, some authors have suggested that this parasite might serve as a biological control for toxic dinoflagellate blooms (Taylor \& Pollingher 1988).

Early studies of Amoebophrya ceratii provided little information about factors that regulate the spread of infections, but generally implied that host abundance and parasite prevalence were positively correlated (Cachon 1964, Taylor 1968). By contrast, Nishitani et al. (1985) argued that high host densities were not a prerequisite for development of epidemics in Alexandrium (= Gonyaulax) catenella and suggested that low nutrient concentrations may contribute to the success of the parasite. Similarly, a negative correlation between parasite prevalence and host abundance was recently reported for Gymnodinium sanguineum populations of Chesapeake Bay (Coats \& Bockstahler 1994). In that system, maximum levels of parasitism were typically associated with low concentrations of $G$. sanguineum near the pycnocline, several meters below dense surface accumulations of lightly infected host assemblages. Additionally, late infections (i.e. just prior to the extracellular reproductive phase of the parasite) were over-represented in host populations at depth, suggesting that parasitized cells either sank out of the surface community or failed to return to the surface following downward migration at night. Thus, interactive effects of organism behavior and stability of the water column during summer appear to vertically segregate infective stages of $A$. ceratil from high concentrations of uninfected hosts and may thereby limit parasite prevalence in the deep central channel of Chesapeake Bay.

If proximity of late infections to uninfected hosts is critical to the success of Amoebophrya ceratii, then this parasite should have a greater influence on host population dynamics in shallow and/or more turbulent environments that maintain greater contact between infected and uninfected individuals. To explore that hypothesis, we examined temporal and spatial aspects in parasitism of 3 host species, Gymnodinium sanguineum, Gyrodinium uncatenum, and Scrippsiella trochoidea, in the shallow Rhode River subestuary of Chesapeake Bay. We also used species-specific distributional patterns and infection levels, along with experimental data, to consider host preference and/or specificity of $A$. ceratii.

\section{MATERIALS AND METHODS}

Study site. The Rhode River is a shallow oligo- to mesohaline embayment of the Chesapeake Bay located on the western shore of Maryland, USA $138^{\circ}$ $52^{\prime} \mathrm{N}, 76^{\circ} 32^{\prime} \mathrm{W}$; Fig. 1). It is contiguous with Muddy Creek, the primary source of freshwater for the subestuary, and joins the West River to form a common mouth on the mainstem of Chesapeake Bay. The subestuary has an area of 550 ha and a mean depth of $2 \mathrm{~m}$, with salinity ranging from $0 \%$ in Muddy Creek during spring to $<20 \%$ at the mouth of the Rhode and West Rivers during fall. Dissolved nutrients are maintained at relatively high background concentrations (Jordan et al. 1991), with periodic increases reflecting runoff from the local watershed and/or remote inputs from the Susquehanna River at the head of Chesapeake Bay (Gallegos et al. 1992). Increased nitrate loading associated with local summer storms stimulates the development of dense dinoflagellate blooms $\left(10^{3}\right.$ to $10^{5}$ cells $\left.\mathrm{ml}^{-1}\right)$ in the upper estuary that are generally dominated by large species, including Gymnodinium spp., Gyrodinium uncatenum, and Scrippsiella trochoidea (Gallegos 1992).

Collection and analysis of field samples. Vertically integrated samples for documenting temporal and spatial occurrence of Amoebophrya ceratii infections in Rhode River populations of Gymnodinium sanguineum, Gyrodinium uncatenum, and Scrippsiella trochoidea were obtained at weekly intervals from spring to early fall 1992, with less frequent sampling (biweekly to monthly) in late fall and winter. On each date, samples were collected at 6 stations along a transect from $1.4 \mathrm{~km}$ downstream to $5.2 \mathrm{~km}$ upstream of 


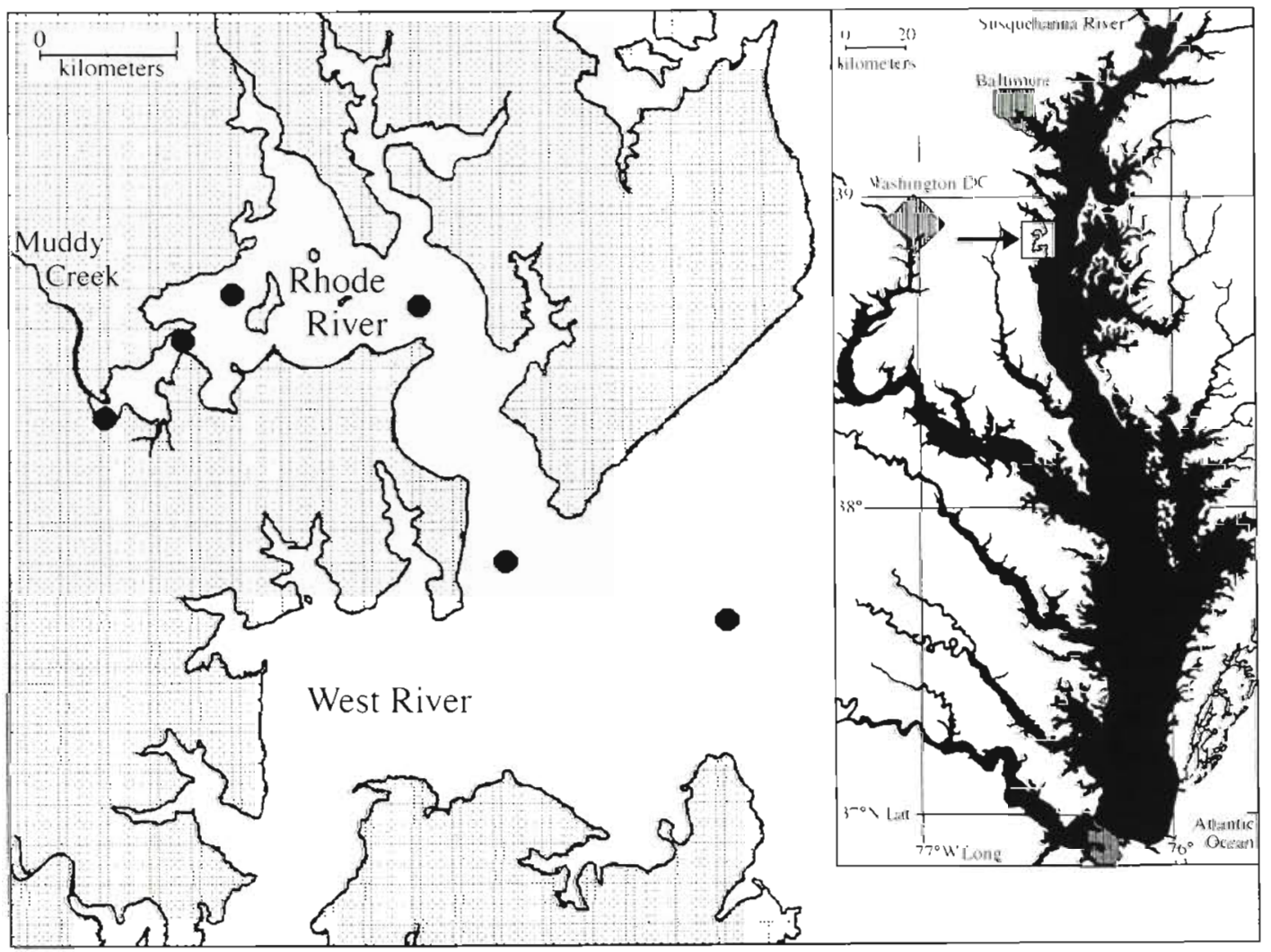

Fig. 1 Routine stations (-) in the Rhode River, USA, with unset showing location of the subestuary on the western shore of Chesapeake Bay

the mouth of the Rhode River (Fig 1); the union of the subestuary with the West River is considered the mouth of the Rhode River Integrated water-column samples were obtained by steadily lowering a 2 l Labline Teflon sampler to just above the sedımentwater interface and then gradually returning the device to the surface before the sample reservoir was completely filled. Subsamples for identification and enumeration of free-living dinoflagellates were preserved using $1 \%$ acid Lugol's solution and later examined by inverted microscopy following procedures of Gallegos (1992). For determining parasite prevalence, subsamples were fixed in a modified Bouin's solution (Coats \& Heinbokel 1982), and 10 to $50 \mathrm{ml}$ aliquots were subsequently stained by the quantitative protargol staining (QPS) technique of Montagnes \& Lynn (1993). Parasite prevalence was determined as previously reported (Coats \& Bockstahler 1994), with at least 100 individuals examined for each host species present at $\geq 0.5$ cells $\mathrm{ml}^{-1}$

Integrated Rhode River values for host abundance and parasite prevalence were calculated as volumeweighted averages using station data and water volumes for discrete portions of the subestuary (segments 1 to 5) as given by Jordan et al. (1991). Parasite in- duced mortality of host species was estimated as: proportion of host population kılled $\mathrm{d}^{-1}=$ (parasite prevalence)(ınfection time) $)^{-1}$ Infection time, $1.65 \mathrm{~d}$ at $23^{\circ} \mathrm{C}$ (Coats \& Bockstahler 1994), was assumed to be the same for all host species and was corrected for ambient temperature using a $Q_{10}$ of 2 .

Laboratory cultures and experiments. Ceratium furca, Gymnodinum sanguineum, and Gyrodinum uncatenum, isolated from Chesapeake Bay by D.W.C., and Scrippsiella trochordea, UTEX strain LB 1017, were cultured in f/2-Si medium (Guillard \& Ryther 1962) formulated using $15 \%$ Bay water supplemented with 5\% (v/v) sollwater [GR+] (Starr \& Zeıkus 1993). Stock cultures were maintained at $23^{\circ} \mathrm{C}$ on a $14: 10 \mathrm{~h}$ light:dark cycle, with cool-white fluorescent bulbs providing $\sim 100 \mu \mathrm{E} \mathrm{m}^{-2} \mathrm{~s}^{-1}$. Amoebophrya ceratil was established in culture by adding a single cell of $G$. sanguineum in late-stage infection to an exponentially growing culture of the same host species. Stock cultures of the parasite were subsequently maintained by transferring aliquots of infected host culture to uninfected $G$. sanguineum stocks at $\sim 3$ intervals.

Transmission of infections in Gymnodinium sanguineum and the ability of Amoebophrya ceratii (ex $G$. sanguineum) to infect Ceratium furca, Gyrodinium un- 
catenum, and Scrippsiella trochoidea were experimentally examined by exposing uninfected cultures to recently formed dinospores, the infective dispersal stage of the parasite. Dinospores $\left(2.5 \times 10^{4} \mathrm{ml}^{-1}\right)$ were separated from hosts by size-fractionation of $2 \mathrm{~d}$ old infected $G$. sanguineum culture using a $12 \mu \mathrm{m}$ Nucleopore filter. Aliquots of dinospores and uninfected, exponentially growing dinoflagellate cultures were added to $20 \mathrm{ml}$ scintillation vials to yield replicate $10 \mathrm{ml}$ volumes for each of 10 treatments represented by: (1) G. sanguineum at $1 \times 10^{3}$ cells $\mathrm{ml}^{-1}$, with dinospore density adjusted over a larige fromin $10^{2}$ to $10^{4} \mathrm{ml}^{-1}(6$ troat ments); (2) C. furca, $G$. uncatenum, and $S$. trochoidea separately, at $1 \times 10^{3}$ cells $\mathrm{ml}^{-1}$, with $5 \times 10^{3}$ dinospores $\mathrm{ml}^{-1}$; and (3) a mixture of the 4 'host' species at $2.5 \times 10^{2} \mathrm{ml}^{-1}$ each, with $A$. ceratii dinospores at $5 \times$ $10^{2} \mathrm{ml}^{-1}$. All vials were lightly capped, incubated for $24 \mathrm{~h}$ under conditions described above, and then preserved with Bouin's solution. Fixed samples were processed by QPS and the percentage of 'hosts' infected by $A$. ceratii determined by examining the first 100 cells encountered on each filter.

\section{RESULTS}

\section{Host and parasite distributions}

Gymnodinium sanguineum, Gyrodinium uncatenum, and Scrippsiella trochoidea represented a progressively larger fraction of total dinoflagellate abundance and accounted for more than $70 \%$ of dinoflagellate biomass along the axis of the Rhode River from late spring through fall of 1992 (Fig. 2). Collectively, these species averaged about 400 cells $\mathrm{ml}^{-1}$ throughout the estuary from May to October, with peak volume-weighted abundance for the Rhode River system reaching 2100 cells $\mathrm{ml}^{-1}$ (Fig. 3A, Table 1). G. uncatenum was the most prominent of these species and occasionally exceeded 30000 cells $\mathrm{ml}^{-1}$ in the upper estuary (Fig. 4A). S. trochoidea was also more prevalent in the mid- to upper Rhode River, where its maximum densities approached 3000 cells m-1 (Fig. 4B, Table 1), while G. sanguineum was primarily restricted to the mid- to lower portion of the estuary and never exceeded 100 cells $\mathrm{ml}^{-1}$ (Fig. 4C). The 3 species also showed temporal differences in peak abundance, with $G$. uncatenum producing multiple blooms between late spring and fall, $S$. trochoidea forming maxima in early to mid summer, and $G$. sanguineum reaching peak concentrations in late summer and fall (Figs. 3B-D \& 4).

Combined infection levels for Gymnodinium sanguineum, Gyrodinium uncatenum, and Scrippsiella trochoidea varied widely during the summer with daily averages for the estuary ranging from 0 to $12 \%$ (Fig. $3 \mathrm{~A}$,

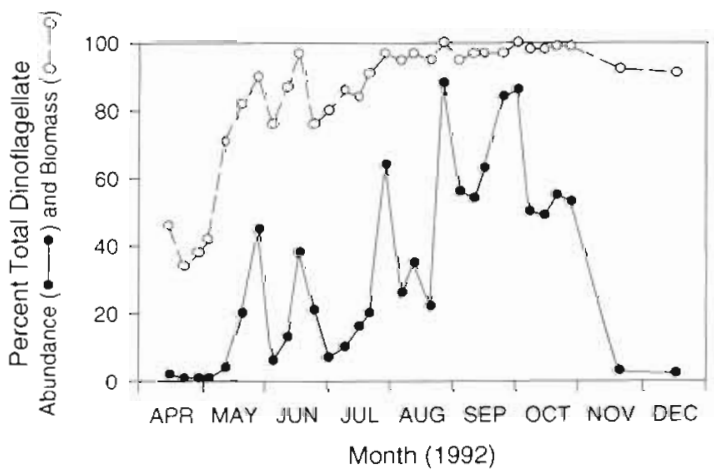

Fig. 2. Proportion of total dinoflagellate abundance $(\bullet)$ and biomass $(0)$ in the Rhode River represented by Gyrodinium uncatenum, Scrippsiella trochoidea, and Gymnodinium sanguineum during 1992. Data represent integrated Rhode River values calculated as volume-weighted averages using station data and water volumes for discrete portions of the subestuary 


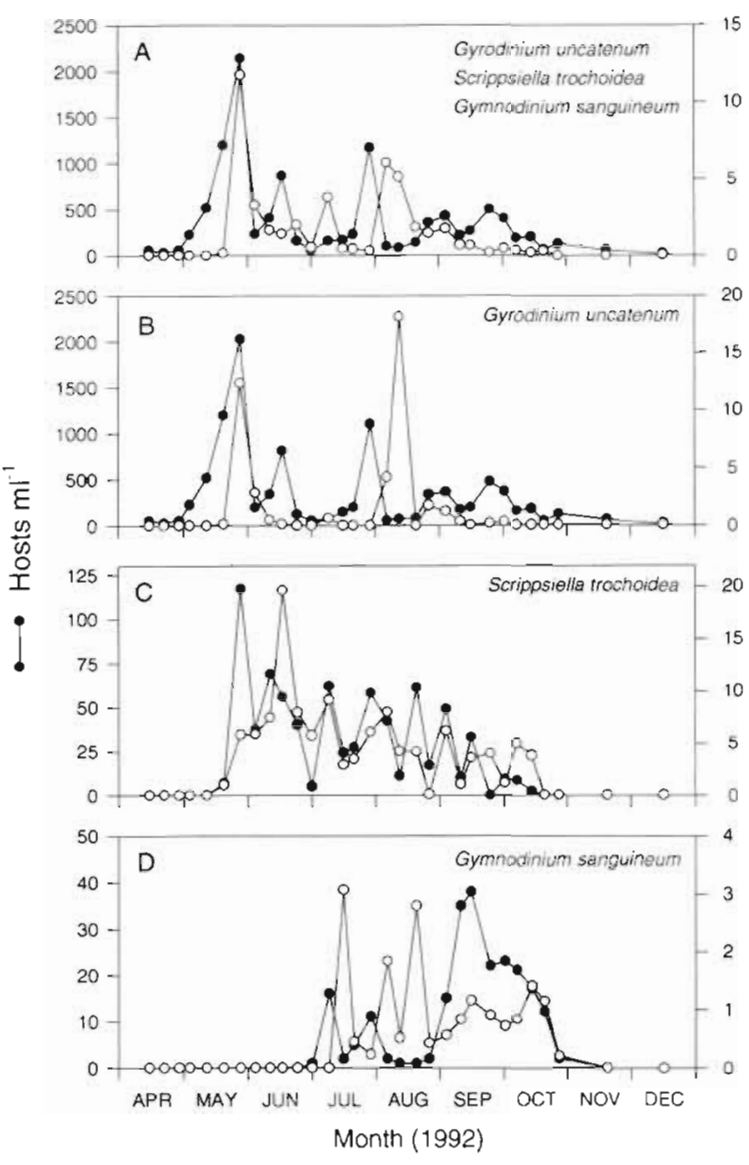

Fig. 3. Integrated Rhode River values for host abundance (•) and parasite prevalence (O) during 1992 calculated as volume-weighted averages using station data and water volumes for discrete portions of the subestuary. (A) Combined data for 3 of the most predominant species. (B) Gyrodinium uncatenum. (C) Scrippsiella trochoidea. (D) Gymnodinium sanguineum

Table 1). Parasitism of individual species showed similar fluctuations, with maximum infection levels coinciding with or following temporal peaks in host abundance (Fig. 3B-D). While average parasite prevalence in the estuary never exceeded $20 \%$ for any of the species, localized epidemics occurred on several occasions, with infection levels of 40 to $80 \%$ persisting for short periods (Fig. 5A-C). Peak infection levels in $G$. uncatenum (60 to $80 \%$ ) were of relatively short duration, and were either followed by a localized decline in host abundance (e.g. in the lower estuary during early May) or were associated with locally depressed host densities between bloom events (e.g. in the upper estuary during mid July). Highest infection levels in S. trochoidea (30 to $40 \%$ ) were also associated with reduced host abundance between bloom events (e.g. in the upper estuary during late May), while less pronounced epidemics $(-20 \%)$ in the lower estuary occurred at low host densities and were not clearly linked to changes in host populations.

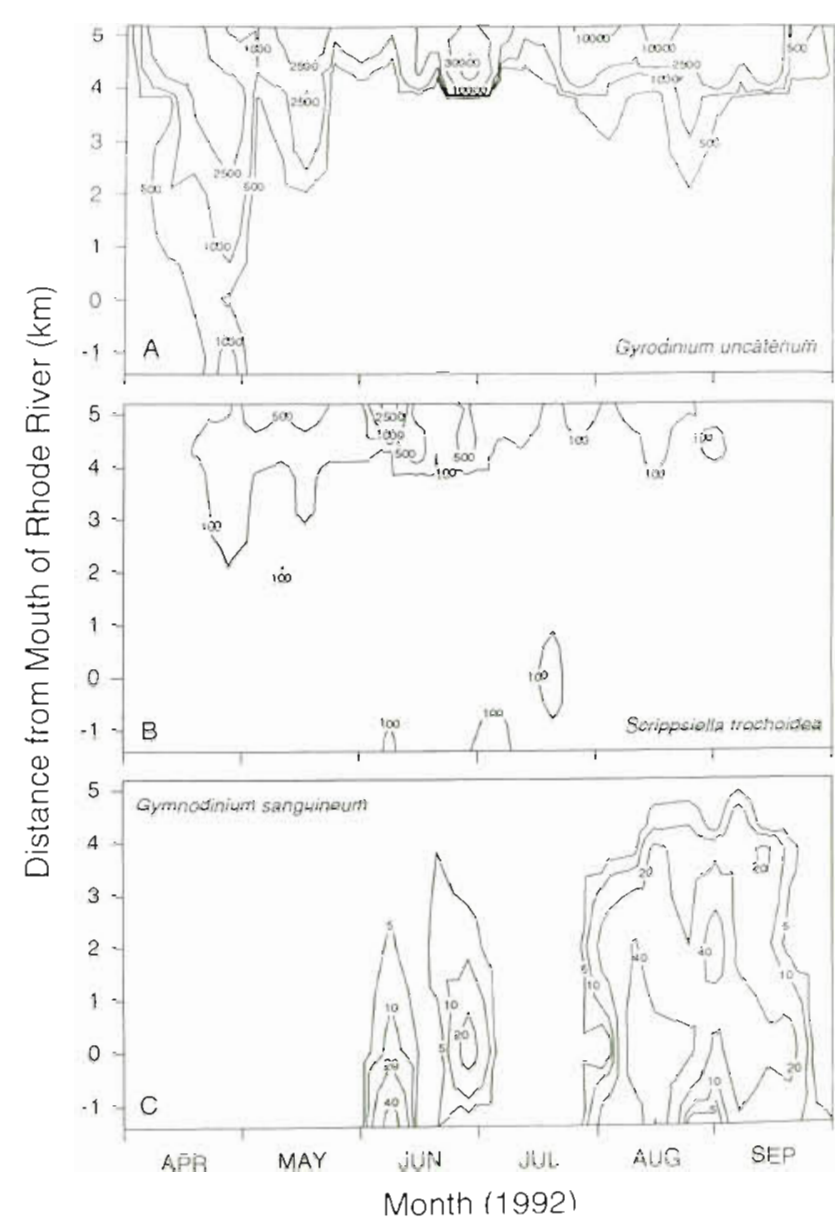

Fig. 4. Distributional contours for abundance $\left(\right.$ cells $\left.\mathrm{ml}^{-1}\right)$ of (A) Gyrodinium uncatenum, (B) Scrippsiella trochoidea, and (C) Gymnodinium sanguineum in the Rhode River during 1992. $y$-axis represents sample distance upstream (positive values) or downstream (negative values) from the confluence of the Rhode and West Rivers

Assuming that generation time of Amoebophrya ceratii is independent of host species, then parasitism of Gymnodinium sanguineum, Gyrodinium uncatenum, and Scrippsiella trochoidea removed about $1 \%$ of cumulative host standing stock $\mathrm{d}^{-1}$ throughout the estuary in summer (Table 1). G. sanguineum appeared to be least affected by $A$. ceratii, with $\leq 2 \%$ of its volume-weighted abundance removed $\mathrm{d}^{-1}$, while comparable values for $G$. uncatenum and $S$. trochoidea reached 12 to $13 \%$. Localized epidemics appeared to have a more pronounced impact on host populations, with parasite induced mortality removing as much as 54,18 and $13 \%$ of host stock $\mathrm{d}^{-1}$ for the 3 species, respectively (Table 1 ).

In most cases, epidemic outbreaks corresponded geographically with high host abundance, but rarely occurred in more that 1 host species simultaneously (cf. Figs. 4 \& 5). For example, high infection levels 


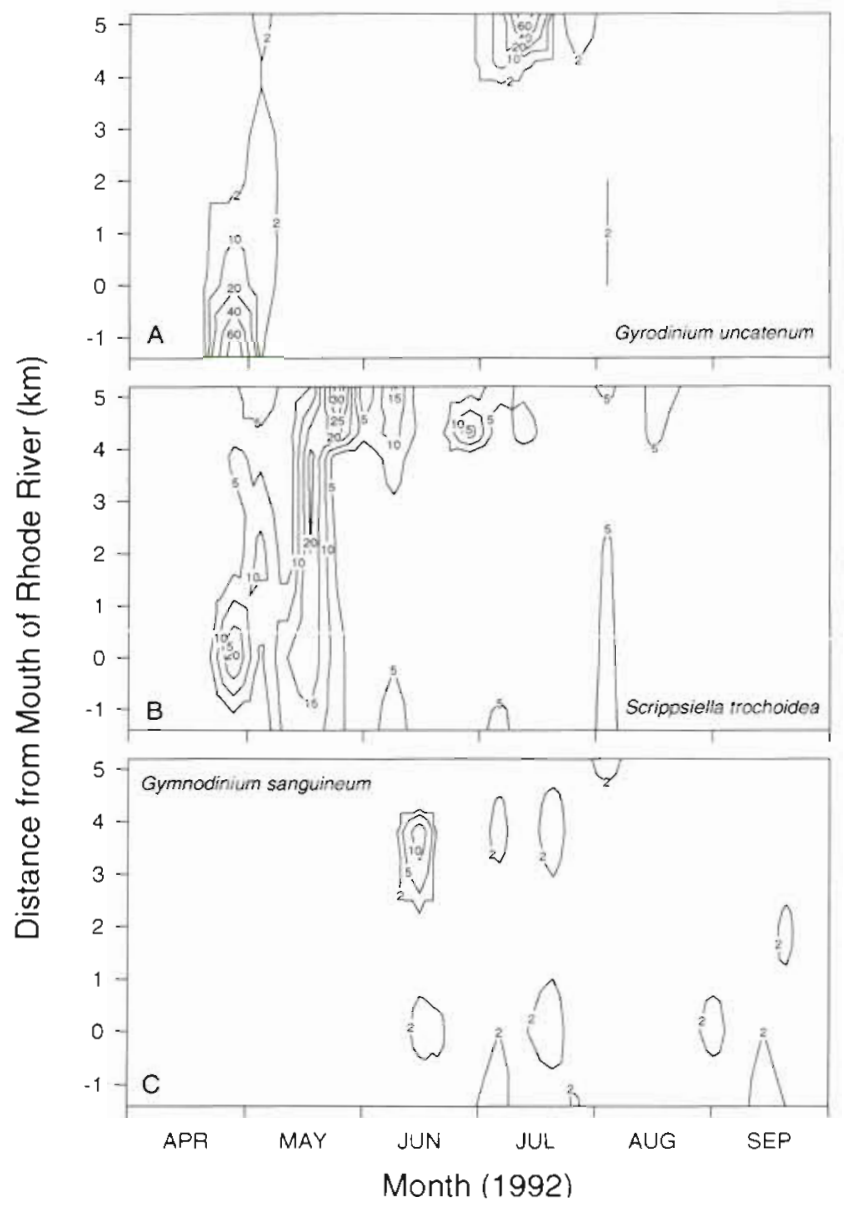

Fig. 5. Distributional contours for parasite prevalence (percent hosts infected) in Rhode River populations of (A) Gyrodinium uncatenum, (B) Scrippsiella trochoidea, and (C) Gymnodinium sanguineum in 1992. $y$-axis as in Fig. 4

(15 to $30 \%$ ) were present in Scrippsiella trochoidea throughout much of the Rhode River in May, while Gyrodinium uncatenum, which was also present at high concentrations (500 to 2500 cells $\mathrm{ml}^{-1}$ ), was relatively unaffected (infection level $<2 \%$ ). Similarly, an epidemic in $G$. uncatenum in the upper estuary during July was not accompanied by increased parasitism in other host species. Only on 1 occasion were epidemic outbreaks temporally coincident in multiple dinoflagellate taxa (viz G. uncatenum and $S$. trochoidea during late April; Fig. 5A, B), and, in that instance, centers of maximum infection for the 2 host species were spatially separated.

\section{Host specificity}

In laboratory studies, dinospores of Amoebophrya ceratii readily infected hosts of the same species, with infection levels in $G$. sanguineum increasing hyperbolically as a function of dinospore abundance (Fig. 6A). At low dinospore densities $\left(\leq 1 \times 10^{3} \mathrm{ml}^{-1}\right)$, each infected host cunldined only 1 parasite; however, parasite load [i.e. parasites (infected host) ${ }^{-1}$ ] increased linearly at higher dinospore abundances (Fig. 6B), with as many as 8 parasites observed in individual host cells. Thus, while the mean number of hosts infected dinospore $e^{-1}$ decreased from 0.200 to 0.092 over the range of $10^{2}$ to $10^{4}$ dinospores $\mathrm{ml}^{-1}$ (data not plotted), the percentage of dinospores that successfully invaded host cells remained relatively constant (Fig. 6; mean for all treatments: $19.4 \pm 1.1 \mathrm{SE}, \mathrm{n}=6$ ).

Amoebophrya ceratii failed to infect Ceratium furca, Gyrodinium uncatenum, and Scrippsiella trochoidea when incubated singly at dinospore densities sufficient to promote high infection levels in $G$. sanguineum (Table 2). Infections also failed to develop in C. furca, $G$. uncatenum, and $S$. trochoidea when incubated in mixed species assemblages in which $G$. sanguineum became moderately infected (Table 2). Interestingly, the percentage of available dinospores that invaded host ( $G$. sanguineum) cells in the mixed species treatment $(18.8 \pm 3.2 \mathrm{SE}, \mathrm{n}=2)$ was the same as that observed in single species incubations reported above.
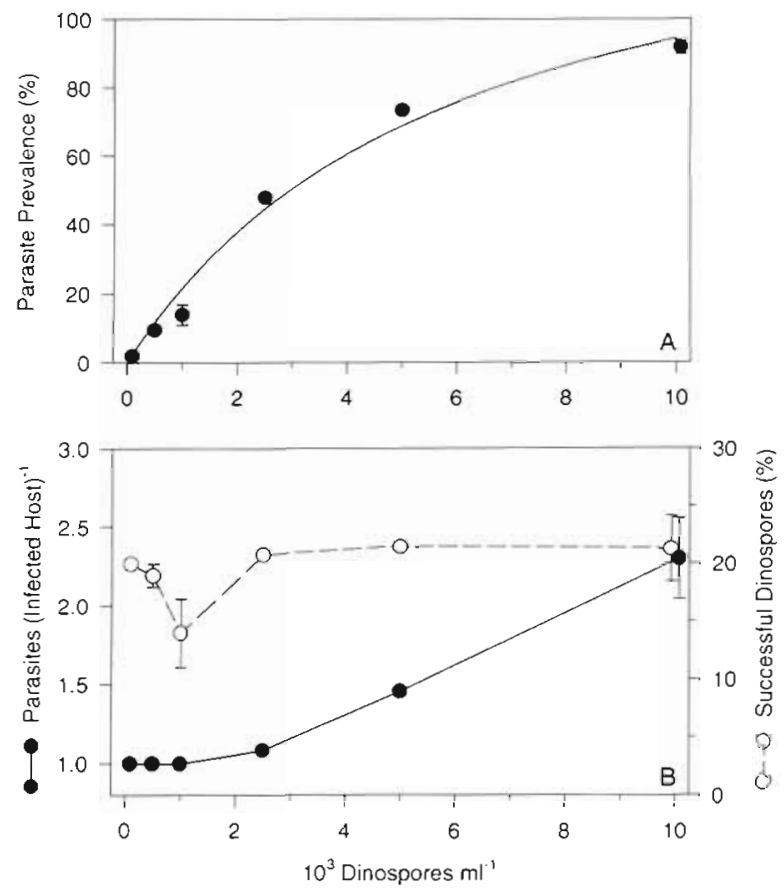

Fig. 6. Infection of Gymnodinium sanguineum by Amoebophrya ceratii in culture. (A) Percent hosts parasitized as a function of dinospore density. (B) Mean number of parasites present inside infected host cells (-) and percent of dinospores that successfully invaded host organisms $(0)$. Error bars represent standard error of means where $n=2$ 
Table 2. Infection of dinoflagellate species following $24 \mathrm{~h}$ exposure to dinospores of Amoebophrya ceratii (ex Gymnodinium sanguineum); mean \pm standard error $(n=2)$

\begin{tabular}{|c|c|c|c|c|c|}
\hline Host species & Hosts $\mathrm{ml}^{-1}$ & Dinospores $\mathrm{ml}^{-1}$ & $\begin{array}{l}\% \text { hosts } \\
\text { infected }\end{array}$ & Parasite load & $\begin{array}{l}\% \text { successful } \\
\text { dinospores }\end{array}$ \\
\hline Gymnodinium sangumeum & $1 \times 10^{3}$ & $5 \times 10^{3}$ & $73.5 \pm 0.5$ & $1.5 \pm 0.03$ & $21.5 \pm 0.3$ \\
\hline Ceratium furca & $1 \times 10^{3}$ & $5 \times 10^{3}$ & 0 & 0 & 0 \\
\hline Gyrodinium uncatenum & $1 \times 10^{3}$ & $5 \times 10^{3}$ & 0 & 0 & 0 \\
\hline Scrippsiella trochoidea & $1 \times 10^{3}$ & $5 \times 10^{2}$ & 0 & 0 & 0 \\
\hline \multicolumn{6}{|l|}{ Mixed species assemblage } \\
\hline G. sanguineum & $2.5 \times 10^{2}$ & $5 \times 10^{2}$ & $34 \pm 5.0$ & $1.1 \pm 0.03$ & $18.8 \pm 3.2$ \\
\hline C. furca & $2.5 \times 10^{2}$ & & 0 & 0 & \\
\hline G. uncatenum & $2.5 \times 10^{2}$ & & 0 & 0 & \\
\hline S. trochoidea & $2.5 \times 10^{2}$ & & 0 & 0 & \\
\hline
\end{tabular}

Thus, the presence of other potential host species did not affect the success of $A$. ceratii in parasitizing $G$. sanguineum.

\section{DISCUSSION}

Spatial and temporal patterns in the abundance of bloom-forming dinoflagellates of the Rhode River and associated prevalence of the intracellular parasite Amoebophrya ceratii were consistent with earlier reports suggesting periodic regulation of red-tide species through parasitism (Cachon 1964, Nishitani et al. 1985). Infection levels were most pronounced in Gyrodinium uncatenum and Scrippsiella trochoidea, with epidemic outbreaks of $A$. ceratii (20 to $80 \%$ of hosts parasitized) associated with short-lived blooms (1 to 2 wk duration) on several occasions. Estimates for parasite induced mortality indicate that $A$. ceratii is capable of removing a significant fraction of host biomass, with epidemics in the upper estuary cropping up to $54 \%$ of the dominant bloom-forming species, $G$. uncatenum, daily. Since infected hosts do not undergo cell division (Coats \& Bockstahler 1994), peak levels of parasitism would offset host reproduction equivalent to about 1 division $\mathrm{d}^{-1}$, near the maximal growth rate for most dinoflagellate species (Banse 1982). Under nutrient replete conditions, $G$. uncatenum exhibits temperature dependent growth ranging from 0.1 to 0.7 divisions $\mathrm{d}^{-1}$ between 12 and $30^{\circ} \mathrm{C}$ (Anderson et al. 1985). Thus, A. ceratii appears capable of exerting a controlling influence on dinoflagellates in the Rhode River, with the potential of causing rapid declines in host abundance when conditions become suboptimal for growth (e.g. with reduced nutrient input from terrestrial runoff or nutrient depletion following bloom formation). However, epidemics were usually localized to relatively small portions of the estuary, with parasitism by $A$. ceratii having less effect on host populations at the system level. During epidemic outbreaks, 12 to $13 \%$ of G. uncatenum and $S$. trochoidea were removed $\mathrm{d}^{-1}$ throughout the estuary, but the impact of parasitism averaged over the summer only represented a daily loss of 1 to $3 \%$ for these species.

Coats \& Bockstahler (1994) suggested that parasitism of Gymnodinium sanguineum by Amoebophrya ceratii in the mainstem of Chesapeake Bay was limited by the vertical separation of infected and uninfected hosts at a critical period in the parasite's life cycle. If true, then infection levels might be expected to increase in systems that prevent physical separation of infected and uninfected hosts. Mean watercolumn prevalence of $A$. ceratii in Rhode River populations of $G$. sanguineum (mean $\pm \mathrm{SE}: 1.0 \pm 0.2 \%, \mathrm{n}=$ 81) was slightly less than that reported for the mainstem of Chesapeake Bay $(2.7 \pm 0.3 \%, n=60$; Coats \& Bockstahler 1994), with maximum values for the 2 areas being comparable, 13 and $11 \%$, respectively. Thus, infection levels in $G$. sanguineum do not appear to be substantially influenced by increased proximity of infected and uninfected cells resulting from the shallower environment of the Rhode River. However, $G$. sanguineum abundance in the Rhode River during $1992\left(<100\right.$ cells $\left.\mathrm{ml}^{-1}\right)$ was substantially less than that previously observed in the mainstem of Chesapeake Bay (bloom concentrations over $10^{3}$ cells $\mathrm{ml}^{-1}$; Coats \& Bockstahler 1994) and, thus, data on infection levels may not provide a good test for our hypothesis. For example, A. ceratii may require threshold concentrations of host organisms to generate heavy infections, with the failure of epidemic outbreaks to develop in Rhode River populations of $G$. sanguineum reflecting the relatively low densities of that species present during 1992. That epidemics did occur in Gyrodinium uncatenum and Scrippsiella trochoidea circumstantially supports our expectation that parasitism among dinoflagellates should be enhanced in shallower regions of Chesapeake Bay; however, the high population densities attained by these species in the Rhode 
River may be of equal or greater importance than physical constraints in facilitating the spread of infections. Unfortunately, such consideration must remain largely speculative, as data on parasitism of $G$. uncatenum and $S$. trochoidea in the mainstem of Chesapeake Bay are not currently available.

The absence of concurrent epidemics in multiple host species may reflect the sequential spread of Amoebophrya ceratii in different host taxa, perhaps due to limitations imposed by changes in host availability or host preference/selectivity. However, the presence of heavy infections in Scrippsiella trochoidea (15 to $30 \%$ ) throughout the Rhode River in May, when dense populations of Gyrodinium uncatenum (500 to 2500 cells $\mathrm{ml}^{-1}$ ) were relatively unaffected (parasite puevalence $<2 \%$, argucs against this interpretation Alternatively, earlier reports that free-living photosynthetic dinoflageliates are only parasitized by a single species of Amoebophrya may be incorrect. In the latter case, temporal and spatial patterns in epidemic infections of Rhode River dinoflagellates may reflect the spread of different parasite species as particular host taxa become more abundant. Interestingly, the description of $A$. ceratii given by Cachon (1964) included some morphological variations that could be interpreted as species distinctions. For example, infections develop in the nucleus of some host taxa, including Gymnodinium sanguineum (Coats \& Bockstahler 1994) and $S$. trochoidea (authors' pers. obs.), but occur intracytoplasmically in other species (e.g. G. uncatenum; authors' pers. obs.). While not conclusive, developmental differences among parasites suggest that dinoflagellates of the Rhode River are parasitized by more than 1 species of Amoebophrya. Further support for this contention is provided by cross-infection experiments that demonstrate the inability of parasites isolated from $G$. sanguineum to infect $G$. uncatenum, $S$. trochoidea, and Ceratium furca under conditions used here. Thus, our estimates for parasite induced mortality for $G$. uncatenum and $S$. trochoidea may be biased, as calculations were based on parasite development time in G. sanguineum, with the possibility of significant differences in timing of developmental events existing for other host species.

When making preliminary observations on parasitism in the toxin-producing dinoflagellate Alexandrium (= Gonyaulax) catenella. Taylor (1968) first suggested that Amoebophrya ceratii might serve as an effective biological control for red tides. Nishitani et al. (1985) later dismissed that possibility, arguing that the lack of host specificity made $A$. ceratii an undesirable, if not impossible, means of altering $A$. catenella abundance. If, however, multiple Amoebophrya spp., each exhibiting some degree of host specificity, have indeed been incorrectly classified as $A$. ceratii, then parasitic interactions in red-tide organisms would be far more complicated than previously recognized. In that situation, Taylor's suggestion would seem to warrant reexamination.

Acknowledgements. Support was provided by research grants from the Smithsonian Institution's programs in Scholarly Studies (D.W.C.) and Environmental Sciences (D.W.C. and C.L.G., separately). We thank K. O'Connell, N. Kobayashi, and C. Jarriel for technical assistance.

\section{LITERATURE CITED}

Anderson DM, Coats DW, Tyler MA (1985) Encystment of the dinoflagellate Gyrodinium uncatenum: temperature and nutrient effects. J Phycol 21:200-206

Banse $K$ (1982) Cell volumes, maximai yrowili lates of unicellular algae and ciliates, and the role of ciliates in the marine pelagial. Limnol Oceanogr 27:1059-1071

Bratbak G, Egge JK, Heldal M (1993) Viral mortality of the marine alga Emiliania huxleyi (Haptophyceae) and termination of algal blooms. Mar Ecol Prog Ser 93:39-48

Bruning K, Lingeman R, Ringelberg J (1992) Estimating the impact of fungal parasites on phytoplankton populations. Limnol Oceanogr 37:252-260

Cachon J (1964) Contribution a l'étude des péridiniens parasites. Cytologie, cycles évolutifs. Ann Sci Nat Zool 6:1-158

Cachon J, Cachon M (1987) Parasitic dinoflagellates. In: Taylor FJR (ed) The biology of dinoflagellates. Blackwell Sci Pub, Oxford, p 571-610

Canter HM, Lund JWG (1948) Studies on plankton parasites 1. Fluctuations in the number of Asterionella formosa Hass in relation to fungal epidemics. New Phytol 47:238-261

Chatton E (1920) Les péridiniens parasites. Morphologie, réproduction, éthologie. Arch Zool Exp Gen 59:1-475

Coats DW, Bockstahler KR (1994) Occurrence of the parasitic dinoflagellate Amoebophrya ceratii in Chesapeake Bay populations of Gymnodinium sanguineum. J Euk Microbiol 41:586-593

Coats DW, Bockstahler KR, Berg GM, Sniezek JH (1994) Dinoflagellate infections of Favella panamensis from two North American estuaries. Mar Biol 119:105-113

Coats DW, Heinbokel JF (1982) A study of reproduction and other life cycle phenomena in planktonic protists usıng an acridine orange fluorescence technique. Mar Bıol 67 : $71-79$

Coats DW, Heisler JJ (1989) Spatial and temporal occurrence of the parasitic dinoflagellate Duboscquella cachoni and its tintinnine host Eutintinnus pectinis in Chesapeake Bay. Mar Biol 101:401-409

Drebes $G$ (1984) Life cycle and host specificity of marine parastic dinoflagellates. Helgoländer Meeresunters 37. $603-622$

Elbrachter M (1973) Population dynamics of Ceratium in coastal waters of Kiel Bay. Oikos 15(Suppl):43-48

Fritz L, Nass M (1992) Development of the parasitic dinoflagellate Amoebophrya ceratii within host dinoflagellate species. J Phycol 28:312-320

Gallegos CL (1992) Phytoplankton photosynthesis, productivity, and species composition in a eutrophic estuary: comparison of bloom and non-bloom assemblages. Mar Ecol Prog Ser 81:257-267

Gallegos CL, Jordan TE, Correll DL (1992) Event-scale response of phytoplankton to watershed inputs in a subestu- 
ary: timing, magnitude, and location of blooms. Limnol Oceanogr 37:813-828

Guillard RRL, Ryther JH (1962) Studies on marine planktonic diatoms. I. Cyclotella nana Hustedt and Detonula confervacea (Cleve) Gran. Can J Microbiol 8:229-239

Heaney SI, Lund JWG, Canter HM, Gray K (1988) Population dynamics of cratium spp. in three English lakes, $1945-$ 1985. Hydrobiologia 161:133-148

Jordan TE, Correll DL, Miklas J, Weller DE (1991) Nutrients and chlorophyll at the interface of a watershed and an estuary. Limnol Oceanogr 36:251-267

Kimmerer WJ, McKinnon AD (1990) High mortality in a copepod population caused by a parasitic dinoflagellate. Mar Biol 107:449-452

Kudoh S, Takahashi M (1990) Fungal control of population changes of the planktonic diatom Asterionella formosa in a shallow eutrophic lake. J Phycol 26:239-244

Montagnes DJS, Lymn DH (1993) A quantitative protargol stain (QPS) for ciliates and other protists. In: Kemp PF, Sherr BF, Sherr EB, Cole JJ (eds) Handbook of methods in aquatic microbial ecology. Lewis Publishers, Boca Raton, p 229-240

Nagasaki K, Ando M, Itakura S, Imai I, Ishida Y (1994) Viral mortality in the final stage of Heterosigma akashiwo (Raphidophyceae) red tide. J Plankton Res 16: $1595-1599$

Nishitani L, Erickson G, Chew KK (1985) Role of the parasitic dinoflagellate Amoebophrya ceratii in control of Gonyaulax catenella populations. In: Anderson DM, White AW, Baden DG (eds) Toxic dinoflagellates. Elsevier Sci Pub Co, lnc, New York, p 225-230

Responsible Subject Editor: R. Sanders, Philadelphia, Pennsylvania, USA.
Reynolds CA (1973) The seasonal periodicity of planktonic diatoms in a shallow eutrophic lake. Freshwater Biol 3 : $89-110$

Sommer U, Wedemeyer C, Lowsky B (1984) Comparison of potential growth rates of Ceratium hirundinella with observed population density changes. Hydrobiologia 109. $159-164$

Spencer R (1955) A marine bacteriophage. Nature 175: $690-691$

Starr RC, Zeikus JA (1993) UTEX - the culture collection of algae at the Unuversity of Texas at Austun. J Phycol 29 (Suppl.):94

Suttle CA (1994) The significance of viruses to mortality in aquatic microbial communities. Microb Ecol 28:237-243

Suttle CA, Chan AM (1995) Viruses infecting the marine prymnesiophyte Chrysochromulina spp.: isolation, preliminary characterization and natural abundance. Mar Ecol Prog Ser 118:275-282

Taylor FJR (1968) Parasitism of the toxin-producing dinoflagellate Gonyaulax catenella by the endoparasitic dinoflagellate Amoebophrya ceratii. J Fish Res Bd Can 25: 2241-2245

Taylor FJR, Pollingher U (1988) Ecology of dinoflagellates. In: Taylor FJR (ed) The biology of dinoflagellates. Blackwell Sci Pub, Oxford, p 398-502

Van Donk E, Ringelberg J (1983) The effect of fungal parasitism on the succession of diatoms in Lake Maarsseveen I (the Netherlands). Freshwater Biol 13:241-251

Youngman RE, Johnson D, Farley MR (1976) Factors influencing phytoplankton growth and succession in Farmoor Reservoir. Freshwater Biol 6:253-263

Manuscript first received: March 18, 1996

Revised version accepted: May 29, 1996 